THE EFFECT OF STOCK RETURN, STOCK RISK, ECONOMIC GROWTH, PROFIT SHARING ON DEPOSIT, COMPANY SIZE AND REVENUE SHARING OF UNDERWRITTING SURPLUS ON INVESTMENT PROPORTION OF SHARIA INSURANCE COMPANIES IN INDONESIAN SHARIAH STOCKS

\title{
PENGARUH RETURN SAHAM, RISIKO SAHAM, PERTUMBUHAN EKONOMI, BAGI HASIL DEPOSITO, UKURAN PERUSAHAAN DAN PENDAPATAN PEMBAGIAN SURPLUS UNDERWRITTING TERHADAP PROPORSI INVESTASI DANA PERUSAHAAN ASURANSI JIWA SYARIAH PADA SAHAM SYARIAH DI INDONESIA
}

\author{
Ulandari, Sulistya Rusgianto \\ Departemen Ekonomi Syariah - Fakultas Ekonomi dan Bisnis - Universitas Airlangga \\ ulandari-2016@feb.uniar.ac.id*, sulistya@feb.unair.ac.id
}

\begin{abstract}
ABSTRAK
Penelitian ini memiliki tujuan untuk menganalisis lebih dalam mengenai faktor-faktor yang mempengaruhi perusahaan asuransi jiwa syariah, dalam mengambil kebijakan besaran proporsi investasi dana persahaan pada saham syariah. Hal ini dilakukan untuk memberikan sebuah wawasan secara teoritis kepada perusahaan dalam mengambil kebijakan mengenai proporsi investasi dana perusahaan. Fokus penelitian ini di Indonesia dengan pendekatan kuantitatif. Data diperoleh dari 10 perusahaan asuransi jiwa syariah yang beroperasi dari 2012 hingga 2018. Metode yang digunakan regresi data panel dengan random effect model. Hasil ipenelitian ini adalah ireturn saham, risiko saham, dan ibagi hasil deposito secara statistik berpengaruh signifikan terhadap proporsi investasi dana perusahaan asuransi jiwa syariah pada saham syariah. Sedangkan pertumbuhan ekonomi, ukuran perusahaan dan pendapatan pembagian surplus underwriting secara statistik tidak berpengaruh terhadap proporsi investasi dana perusahaan asuransi jiwa syariah pada saham syariah.

Kata Kunci: Proporsi Investasi, Return Saham, Risiko Saham, Pertumbuhan Ekonomi, Bagi Hasil Deposito, Ukuran Perusahaan dan Pendapatan Pembagian Surplus Underwritting
\end{abstract}

\footnotetext{
ABSTRACT

This study aimed to analyze more deeply the factors that influence sharia life insurance companies in making a policy of the proportion of investment in company funds in sharia stocks. This study to provide a theoretical insight into the company in making policy regarding the proportion of the company's investment funds to adapt it to the circumstances experienced by the company. Focus of research in Indonesia with quantitative approach which data collected from 10 sharia life insurance companys financial statements among 2012 until 2018. Method of research uses regression panel data with random effect model. The results of this study were stock returns, stock risk, and profit-sharing on deposits had a significant effect on the proportion of investment in Islamic life insurance company funds in sharia stocks. Meanwhile, economic growth, company size, and revenue sharing of the underwriting surplus do not affect the proportion of sharia life insurance company investment in sharia stocks.

Keywords: Investment Proportion, Stock Returns, Stock Risk, Economic Growth, Deposit Profit Sharing, Company Size and Income Share of the Underwriting Surplus
}

Informasi artikel

Diterima: 11-11-2020

Direview: 11-11-2020

Diterbitkan: 29-1 1-2020

*)Korespondensi

(Correspondence):

Ulandari

Open access under Creative Commons Attribution-Non Commercial-Share A like 4.0 International Licence (CC-BY-NC-SA) (c) (1) (2) 
Ulandari, et al/Jurnal Ekonomi Syariah Teori dan Terapan Vol. 7 No. 11 November 2020: 22672285

\section{PENDAHULUAN}

\section{Latar Belakang}

Di Indonesia, asuransi syariah dikenal dengan takaful. Takaful berasal dari "takafala-yatafakalu" yang artinya saling menjamin atau menanggung antara satu sama lain. Asuransi syariah dalam muamalah merupakan menanggung risiko diantara sesama. Sehingga satu orang bertanggung jawab atas risiko orang lain (Sherif \& Azlina Shaairi, 2013). Asuransi syariah dalam bahasa Arab disebut "kafala" yang berarti penanggung jawab. Asuransi syariah memberikan keamanan atau perlindungan terhadap keadaan masa depan tertentu bagi individu atau bisnis (Raza et al., 2019). Perusahaan asuransi berperan mengelola dana yang telah dihimpun melalui penyediaan jasa asuransi untuk memberikan jaminan kepada peserta yang mengalami musibah di masa mendatang.

Perusahaan asuransi harus memenuhi kewajiban untuk meningkatkan modal atau laba agar mampu meningkatkan daya saing dan memperkuat kesehatan kevangan. Dalam putusan DSN-MUI NO:21/DSN$\mathrm{MUI} / \mathrm{X} / 2001$ menyebutkan bahwa, perusahaan asuransi selaku pemegang amanah wajib melakukan investasi dari dana yang telah terkumpul sesuai dengan prinsip syariah. Seperti yang disebutkan dalam peraturan Otoritas Jasa Keuangan nomor 72/POJK.05/2016 mengenai Kesehatan Keuangan Perusahaan Asuransi dan Perusahaan
Reasuransi dengan Prinsip Syariah pada pasal 13, bahwa aset yang diperkenankan dari dana tabarru', dana tanahud, dan dana perusahaan dalam bentuk investasi salah satunya adalah saham syariah.

Investasi merupakan salah satu kegiatan muamalah yang dianjurkan Islam. Islam mengajarkan kepada kita agar tidak menghabiskan harta kekayaan yang dimiliki, tetapi hendaknya sebagian kekayaan itu ditangguhkan pemanfaatannya untuk keperluan yang lebih penting. Dengan kata lain Islam mengajarkan kita agar mengelola dan mengembangkan harta yang dimiliki untuk kepentingan di masa mendatang. Islam mengajarkan umatnya untuk berusaha mendapatkan kehidupan yang lebih baik di dunia maupun di akhirat. Memperoleh kehidupan yang baik di dunia maupun akhirat ini dapat menjamin tercapainya kesejahteraan lahir dan batin. Salah satu cara untuk mencapai kesejahteraan tersebut adalah dengan melakukan kegiatan investasi. Sesuai dengan firman Allah dalam QS. Al-Baqarah: 261

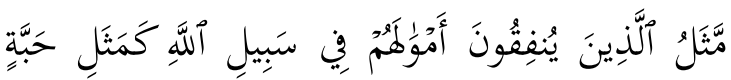

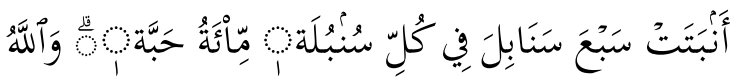

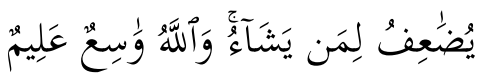
Maśalullażina yunfiqụna amwālahum fi sabililāhi kamaśali habbatin ambatat sab'a sanābila fi kulli sumbulatim mi atu habbah, wallāhu yudā'ifu limay yasyā', wallāhu wāsi'un 'alım

Artinya: "Perumpamaan orang yang menginfakkan hartanya di jalan Allah seperti sebutir biji yang menumbuhkan 
Ulandari, et al/Jurnal Ekonomi Syariah Teori dan Terapan Vol. 7 No. 11 November 2020: 22672285

tujuh tangkai, pada setiap tangkai ada seratus biji. Allah melipatgandakan bagi siapa yang Dia kehendaki, dan Allah Mahaluas, Maha Mengetahui" (Sumber: Qur'an Kementrian Agama).

Ayat ini menjelaskan tentang bagaimana sebutir benih yang ditanam pada tanah yang baik dan menumbuhkan sebatang pohon, pada umumnya menghasilkan lebih dari setangkai buah bahkan ada yang berjumlah lebih dari lima puluh tangkai. Dengan demikian jelas bahwa penggambaran yang diberikan ayat tadi bahwa sebutir benih dilipat gandakan hasilnya sampai menjadi tujuh ratus butir (Tafsir Kemenag Rl, 2020). Ayat ini juga menjelaskan mengenai investasi meskipun tidak secara kongkrit berbicara investasi.

Dalam memenuhi kewajiban untuk meningkatkan modal atau laba, perusahaan asuransi jiwa syariah melakukan investasi atas dana yang telah dihimpun. Dalam pengelolaan dana, perusahaan asuransi tidak bisa sembarangan menetapkan besaran proporsi investasi. Jumlah proporsi investasi dana perusahaan asuransi jiwa syariah pada saham terbilang masih sangat rendah karena dalam periode 2012-2018 proporsi investasi tertinggi hanya mencapai 3,5\%. Sedangkan dalam peraturan Otoritas Jasa Keuangan nomor 72/POJK.05/2016 pasal 19 ayat (1) menyebutkan bahwa untuk setiap emiten maksimal $10 \%$ dari jumlah investasi dan secara keseluruhan maksimal $40 \%$ dari jumlah investasi.
Tabel 1.

Proporsi Investasi Saham Perusahaan Asuransi Jiwa Syariah

\begin{tabular}{cc}
\multicolumn{2}{c}{ Syariah } \\
\hline Tahun & Proporsi Investasi \\
\hline 2012 & $0.11 \%$ \\
2013 & $0.71 \%$ \\
2014 & $1.21 \%$ \\
2015 & $1.32 \%$ \\
2016 & $0.90 \%$ \\
2017 & $1.01 \%$ \\
2018 & $3.47 \%$ \\
\hline
\end{tabular}

Sumber: OJK (data diolah)

Dari tabel 1 menunjukkan proporsi investasi pada saham mengalami kecenderungan naik dari tahun ke tahun, namun masih jauh dari batas maksimal yang diijinkan yaitu sebesar $40 \%$. Investasi saham merupakan salah satu jenis investasi yang memiliki tingkat risiko tinggi. Walaupun berisiko tinggi, investasi pada saham menjanjikan return yang tinggi pula. Sehingga untuk mengoptimalkan investasi sekaligus mengurangi kemungkinan terjadinya risiko, maka perusahaan asuransi membentuk portofolio investasi.

Berdasarkan latar belakang diatas, penelitian ini bertujuan untuk menganalisis mengenai faktor-faktor yang mempengaruhi perusahaan asuransi jiwa syariah dalam mengambil kebijakan besaran proporsi investasi dana perusahaan pada saham syariah. Hal ini dilakukan untuk memberikan sebuah wawasan secara teoritis kepada perusahaan asuransi dalam mengambil kebijakan proporsi investasi dana perusahaan.
II. LANDASAN
TEORI
DAN

\section{Asuransi Syariah}


Ulandari, et al/Jurnal Ekonomi Syariah Teori dan Terapan Vol. 7 No. 11 November 2020: 22672285

Asuransi syariah dalam bahasa Arab disebut "kafala" yang memiliki makna penanggung jawab. Asuransi syariah memberikan keamanan atau perlindungan terhadap keadaan masa depan tertentu bagi individu atau bisnis (Raza et al., 2019). Asuransi konvensional dilarang dalam Islam karena adanya "gharar" (ketidakpastian), riba (bunga) dan maisir (perjudian). Hal tersebut bertentangan dengan hukum syariah (Raza et al., 2019). Prinsip dasar asuransi syariah adalah upaya di antara sejumlah orang/pihak untuk saling melindungi dan membantu melalui investasi pada aset dan/atau dana tabarru' memberikan pola pengembalian untuk menghadapi risiko tertentu melalui kontrak sesuai dengan hukum Islam (Alam Choudhury \& Harahap, 2009).

\section{Investasi Syariah}

Investasi pada dasarnya meletakan sejumlah modal ke dalam beberapa bentuk instrumen (Kane et al., 2016). Salah satu kegiatan muamalah yang diijinkan dan dianjurkan oleh Islam adalah Investasi. Namun dalam Islam, melarang berinvestasi pada investasi yang produk sistem pengelolaannya tidak sesuai dengan aturan Islam. Investasi yang dianjurkan adalah yang tidak mengandung riba, gharar, dan maisir (Mashuri, 2018).

Salah satu efek syariah yang menjadi fokus dalam penelitian ini yaitu saham syariah. Pemilihan saham harus disesuaikan dengan prinsip syariah.

\section{Portofolio Investasi}

Setiap investor sudah pasti akan dihadapkan dengan penentuan besaran proporsi dana yang akan diinvestasikan. Menentukan besaran proporsi dalam investasi merupakan hal yang sering dibicarakan, namun berinvestasi dengan optimal dan efisien bukanlah hal yang mudah. Salah satu cara untuk mengoptimalkan investasi sekaligus mengurangi kemungkinan terjadinya risiko maka digunakan diversifikasi portofolio (Husnan, 1994). Manfaat diversifikasi telah dikenal baik melalui prinsip "jangan meletakkan semua telur dalam satu keranjang". Artinya apabila ikeranjang tersebut jatuh maka telurnya akan pecah semua. Begitu pula dengan investasi sebab apabila hanya meletakkan seluruh modal pada satu aset, kemudian aset tersebut jatuh atau merugi maka investor yang telah menginvestasikan dananya mengalami kerugian (Zubir, 2011). Secara lebih khusus dalam penelitian ini yang dimaksud portofolio investasi yaitu meletakkan proporsi investasi nya pada saham syariah.

PROINV

$$
=\frac{\text { Jumlah keseluruhan investasi di saham }}{\text { Jumlah keseluruhan investasi }}
$$

\section{Return dan Risiko Saham}

Tambahan pendapatan yang diterima atas kegiatan investasi ditambah harga pasar setiap perusahaan dan dinyatakan dalam presentase disebut dengan return (Kuhlemeyer, 2004). Return menjadi salah satu faktor penting yang 
Ulandari, et al/Jurnal Ekonomi Syariah Teori dan Terapan Vol. 7 No. 11 November 2020: 22672285

dipertimbangkan investor untuk melakukan investasi.

Dalam investasi, tidak bisa hanya memperhitungkan return saja. Risiko juga harus diperhitungkan. Risiko merupakan kemungkinan terkena kerugian (Virlics, 2013). Menurut Brigham and Daves (2004) Risiko saham dibedakan menjadi dua macam, yaitu risiko sistematis (systematic risk) dan risiko tidak sistematis (unsystematic risk). Risiko sistematis merupakan risiko yang tidak dapat dihindari, seperti faktor-faktor makro yang dapat mempengaruhi pasar secara keseluruhan seperti keadaan ekonomi dan politik. Sedangkan risiko tidak sistematis merupakan risiko yang tidak terkait dengan kondisi pasar investasi yang dapat dihindari melalui diversifikasi saham dengan membentuk portofolio optimal. Untuk menghitung risiko yaitu menggunakan standar deviasi (Hartono, 2016:305).

Pandangan Islam mengenai return dan risiko adalah Al ghunmu bil ghurmi yang artinya risiko akan selalu menyertai setiap ekspetasi return. Hubungan antara return dan risiko merupakan dua hal yang tidak dapat dipisahkan, karena pertimbangan investasi merupakan tradeoff dari kedua faktor tersebut.

Dalam penelitian ini, menggunakan rata-rata return geometrik. Rata-rata geometrik digunakan untuk menghitung rata-rata yang memperhatikan tingkat pertumbuhan kumulatif dari waktu ke waktu (Jogiyanto, 2017:296). Rata-rata return geometrik dihitung dengan rumus:

$$
R G=\{(1+R 1)(1+R 2) \ldots(1+R n)\} 1 / n-1
$$

Keterangan:

$$
\begin{array}{ll}
\mathrm{RG} & =\text { Rata-rata return geometrik } \\
\mathrm{Ri} & =\text { Return untuk periode ke-i } \\
\mathrm{n} & =\text { jumlah dari return } \\
& \text { Perhitungan risiko menggunakan }
\end{array}
$$

standar deviasi. Menurut Jogiyanto (2016:307), risiko yang diukur dengan standar deviasi dapat dihitung dengan rumus sebagai berikut ini.

$\mathrm{SD}=\sqrt{\sum_{i=1}^{\Pi} \frac{\left(X_{i}-E\left(X_{i}\right)\right)^{2}}{n-1}}$

Keterangan:

$$
\begin{array}{ll}
\mathrm{SD} & : \text { standar deviasi } \\
X_{i} & : \text { Nilai ke-i } \\
\mathrm{E}\left(X_{i}\right) & : \text { Nilai ekspektasian } \\
\mathrm{n} & : \text { Jumlah dari obeservasi data }
\end{array}
$$

\section{Pertumbuhan Ekonomi}

Bagi investor pertumbuhan ekonomi tidak jarang menjadi salah satu alasan atau faktor yang menjadi bahan pertimbangan untuk melakukan investasi. Karena menurun atau meningkatnya kinerja pasar modal didorong oleh pertumbuhan ekonomi. Salah satu indikator untuk mengetahui perkembangan perekonomian suatu negara pada periode tertentu adalah melalui Produk Domestik Bruto (BI, 2019). PDB dihitung pada suatu negara di periode tertentu melalui nilai pasar seluruh barang dan jasanya (Mankiw, 2014).

$$
\text { Kegiatan perekonomian yang }
$$
meningkat pada suatu negara menunjukkan terjadinya peningkatan pada nilai PDB di negara tersebut. Artinya, negara tersebut sedang mengalami 
Ulandari, et al/Jurnal Ekonomi Syariah Teori dan Terapan Vol. 7 No. 11 November 2020: 22672285

peningkatan aktivitas ekonomi, lebih banyak barang atau jasa yang dihasilkan. Hal tersebut berpotensi pada peningkatan laba perusahaan, sehingga perusahaan dapat lebih besar menetapkan proporsi investasi. Sebaliknya, kegiatan perekonomian yang melemah menunjukkan penurunan nilai PDB di suatu negara. Artinya, negara tersebut mengalami penurunan aktivitas ekonomi, lebih sedikit barang atau jasa yang dihasilkan. Hal tersebut berpotensi pada penurunan laba perusahaan. Namun, meskipun kondisi pertumbuhan ekonomi baik, tetap akan ada perusahaan yang berpotensi mengalami penurunan aktivitas ekonomi.

$R P D B=\frac{P D B_{t}-P D B_{t-1}}{P D B_{t-1}} \times 100 \%$

Keterangan:

RPDB = Laju pertumbuhan ekonomi dalam satuan persen

$P D B_{t}=$ Produk Domestik Bruto pada tahun tertentu

$P D B_{t-1}=$ Produk Domestik Bruto pada tahun sebelumnya

\section{Bagi Hasil Deposito}

Salah satu sistem yang dipergunakan perbankan syariah dalam pembagian hasil usaha dari beberapa pihak dimana pemilik dana bekerjasama dengan pengelola dana untuk melakukan suatu kegiatan usaha disebut dengan bagi hasil (Rofiq, 2004: 153). Deposito sendiri merupakan salah satu bentuk investasi dengan jangka waktu tertentu dalam bentuk mata uang rupiah. Pada deposito bank syariah, nasabah bertindak selaku shahibul maal atau pemilik dana sedangkan bank syariah selaku mudharib atau pengelola dana. Deposito mudharabah merupakan salah satu bentuk investasi dimana bila mendapatkan keuntungan dibagi kedua belah pihak sesuai dengan kesepakatan di awal. Mengenai pengaruh bagi hasil deposito terhadap proporsi investasi pada saham terdapat dua kemungkinan. Pertama, jika bagi hasil deposito bepengaruh negatif terhadap proporsi investasi pada saham. Artinya jika bagi hasil deposito yang diperoleh tinggi, perusahaan asuransi akan mengurangi proporsi investasi dananya pada saham dan mengalokasikan dana tersebut pada deposito. Kedua, jika bagi hasil deposito berpengaruh positif. Artinya dengan bagi hasil yang diterima tinggi, maka bagi hasil deposito tersebut dapat dijadikan andalan sebagai pendapatan return. Hal tersebut mengakibatkan perusahaan asuransi lebih berani mengambil risiko pada saham syariah dan menambah proporsi saham.

\section{Ukuran Perusahaan Asuransi}

Salah satu faktor internal yang sering menjadi pertimbangan perusahaan asuransi syariah dalam menentukan besaran proporsi investasi adalah ukuran perusahaan. Ukuran perusahaan dapat diketahui melalui total asset pada laporan keuangan setiap perusahaan. Jika perusahaan tersebut memiliki total asset yang besar, maka manajer investasi perusahaan lebih leluasa dalam mengalokasikan aset perusahaan untuk kebutuhan perusahaan. Ukuran 
Ulandari, et al/Jurnal Ekonomi Syariah Teori dan Terapan Vol. 7 No. 11 November 2020: 22672285

perusahaan juga dapat menggambarkan besar atau kecilnya suatu perusahaan. Pengelompokkan ukuran perusahaan berdasarkan skala operasinya dibedakan menjadi tiga macam, yaitu perusahaan besar, perusahaan menengah, dan perusahaan kecil (Kinoshita, 2005). Ukuran perusahaan diukur menggunakan logaritma natural (In) dari total aktiva yang dimiliki perusahaan (Harahap, 2007:23).

$U K P=\ln ($ total ase $)$

Keterangan:

UKP = Ukuran perusahaan asuransi jiwa syariah

In = Logaritma natural

\section{Pendapatan \\ Pembagian \\ Underwritting}

Surplus

Pendapatan pembagian surplus underwriting adalah bagian sejumlah dana yang didapat perusahaan perusahaan atas terjadinya surplus underwriting. Pada hakikatnya surplus underwriting dana tabarru adalah milik peserta. Namun pada aturan Fatwa DSN No.53/DSN-MUI/III/2006 menyatakan, jika terdapat surplus dalam underwriting dana tabarru', perusahaan asuransi dapat memperlakukan surplus underwriting pada tiga pilihan. Pertama, seluruhnya disimpan sebagai dana cadangan. Kedua, disimpan sebagian sebagai dana cadangan dan dibagikan sebagian lainnya kepada para peserta asuransi sesuai syarat. Ketiga, disimpan sebagian sebagai dana cadangan, dibagikan sebagian kepada perusahaan dan peserta asuransi sesuai dengan kesepakatan. Salah satu tolak ukur yang menunjukkan pengelolaan dana peserta dalam perusahaan asuransi adalah underwriting. Secara umum proses underwriting yang telah dilakukan dengan baik, akan menunjukkan peningkatan surplus underwriting pada perusahaan asuransi. Sedangkan memburuknya proses underwriting, ditunjukkan dengan penurunan hasil underwriting (Fikri, 2009).

$P P S U=\ln ($ Pendapatan pembagian surplus underwritting)

Keterangan:

PPSU = Pendapatan Pembagian Surplus Underwritting

In = Logaritma natural

Hipotesis

Berdasarkan latar belakang, rumusan masalah, maka hipotesis dalam penelitian ini sebagai berikut:

$\mathrm{H} 1_{1}=$ Return saham berpengaruh terhadap proporsi investasi.

$\mathrm{Hl}_{2}=$ Risiko saham berpengaruh terhadap proporsi investasi.

$\mathrm{H}_{3}=$ Pertumbuhan ekonomi berpengaruh terhadap proporsi investasi.

$\mathrm{Hl}_{4}=$ Bagi hasil deposito berpengaruh terhadap proporsi investasi.

$\mathrm{H}_{5}=$ Ukuran perusahaan berpengaruh terhadap proporsi investasi.

$\mathrm{H}_{6}=$ Pendapatan pembagian surplus underwriting berpengaruh terhadap proporsi investasi.

$\mathrm{Hl}_{7}=$ Return saham, risiko saham, pertumbuhan ekonomi, bagi hasil deposito, ukuran perusahaan dan pendapatan pembagian surplus underwriting secara simultan 
Ulandari, et al/Jurnal Ekonomi Syariah Teori dan Terapan Vol. 7 No. 11 November 2020: 22672285

berpengaruh terhadap proporsi investasi.

\section{Penelitian Terdahulu}

Hubungan antara faktor-faktor yang dapat mempengaruhi proporsi investasi telah dilakukan oleh beberapa peneliti sebelumnya dengan berbagai hasil dan proksi. Terkait sampel dan variabel yang digunakan yakni, Ward ef al., (2014) melakukan penelitian pada perusahaan asuransi di 9 negara OECD menemukan bahwa pertumbuhan ekonomi tidak mempengaruhi aktivitas perusahaan asuransi. Terdapat pengaruh sejumlah faktor spesifik negara, seperti budaya, lingkungan hukum, peningkatan intermediasi kevangan dan dampak pertanggungan moral hazard; Yakob et al., (2015) melakukan penelitian pada perusahaan asuransi jiwa syariah di Malaysia menemukan bahwa sistem operasi dan produk terkait investasi meningkatkan efisiensi manajemen investasi dari perusahaan asuransi. Sedangkan untuk ukuran perusahaan tidak memberikan pengaruh terhadap efisiensi manajemen investasi perusahaan asuransi; dan Kinoshita, (2005) melakukan penelitian pada perusahaan manufaktur di Jepang menunjukkan bahwa perusahaan dengan ukuran yang berbeda memliki respon terhadap faktor yang menentukan pembuatan keputusan investasi asing dengan cara yang berbeda pula.

Biaya tenaga kerja yang rendah dan infrastruktur yang cukup mendorong perusahaan kecil berinvestasi di negara yang pasti. Sedangkan perusahaan besar dapat berinvestasi pada negara dengan ukuran pasar dan pertimbangan yang lebih strategis dalam mengambil keputusan. Secara umum, investasi dipengrauhi oleh ukuran perusahaan, sufficient infrastuktur, kebijakan lingkungan yang baik, dan persaingan strategis intra industry; Zhu \& Zhou, (2009) meneliti mengenai alokasi aset yang dipengaruhi oleh retun saham, risiko, tingkat prediktibilitas, dan harga pasar. Ketika return dapat diramalkan, nilai tambah analisis teknikal dalam alokasi aset menjelaskan kecenderungan investor melakukan investasi dengan proporsi tetap pada saham. Berdasarkan besaran kerugian dalam masalah alokasi aset, penting untuk mengetahui return saham secara dinamis dan strategi optimalisasinya melalui analisis teknikal. Alokasi aset merupakan fungsi dari risk aversion investor dan derajat kemungkinan return saham. Sehingga dapat dikatakan bahwa alokasi aset dipengaruhi oleh risiko yang mau diterima investor dan return yang diharapkan; Arouri et al. (2013) melakukan penelitian pada investasi produk keuangan Islam dengan variabel return dan risiko menunjukkan bahwa investasi pada produk keuangan Islam menghasilkan return yang tinggi.

Hal ini mengartikan bahwa investasi produk Islam juga memiliki risiko yang tinggi. Portofolio yang menggunakan produk keuangan Islam dapat mengurangi risiko sistematis (sehingga expected return meningkat) dan menghasilkan keuntungan diversifikasi yang signifikan; 
Ulandari, et al/Jurnal Ekonomi Syariah Teori dan Terapan Vol. 7 No. 11 November 2020: 22672285

Penelitian Yesha (2018) melakukan penelitian dengan objek PT Bank Nagari Utama Padang dan menggunakan time series. Hasil pada penelitian menunjukkan bahwa tingkat bagi hasil berpengaruh positif signifikan terhadap simpanan deposito.

Berdasarkan hasil dari penelitian sebelumnya, maka terdapat hubungan yang erat antara faktor-faktor yang mempengaruhi perusahaan asuransi jiwa dalam mengambil kebijakan besaran proporsi investasi dana perusahaan.

\section{METODE PENELITIAN}

\section{Model Empiris}

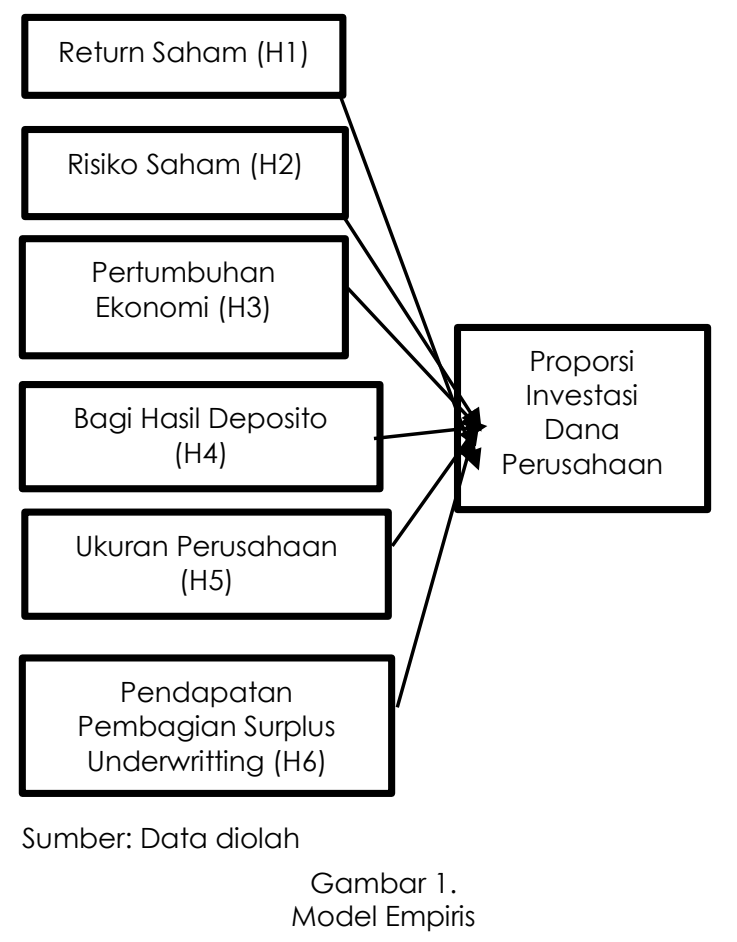

Penelitian ini menggunakan pendekatan kuantitatif regresi data panel dengan model random effect. Pendekatan kuantitatif digunakan dalam penelitian untuk mengetahui pengaruh variabel independen yaitu return saham, risiko saham, pertumbuhan ekonomi, bagi hasil deposito, ukuran perusahaan, dan pendapatan pembagian surplus underwriting dalam mempengaruhi variabel dependen yaitu proporsi investasi dana perusahaan pada saham syariah pada subjek penelitian yaitu asuransi jiwa syariah di Indonesia periode 2012-2018.

\section{Jenis dan Sumber Data}

Data yang digunakan berupa data sekunder yang berasal dari website resmi Otoritas Jasa Keuangan (OJK), Badan Pusat Statistik (BPS), Yahoo Finance dan laporan kevangan tahunan asuransi jiwa syariah. Sampel yang digunakan sebanyak 10 perusahaan asuransi jiwa syariah baik berbentuk full fledge ataupun unit usaha untuk periode tahun 2012-2018.

\section{Populasi}

Populasi pada penelitian ini adalah 30 perusahaan asuransi jiwa syariah yang telah terdaftar di Otoritas Jasa Kevangan, baik perusahaan yang berbentuk full fledge syariah maupun unit usaha syariah. Sampel

Metode pengambilan sampel menggunakan teknik purposive sampling yaitu menentukan kriteria khusus terhadap sampel (Priyono, 2003) dengan kriteria sebagai berikut:

1. Perusahaan asuransi jiwa syariah terdaftar di Otoritas Jasa Keuangan dan beroperasi dalam periode 20122018

2. Perusahaan asuransi jiwa syariah memiliki laporan keuangan tahunan 2012-2018 secara lengkap yang dapat diakses oleh umum baik dari website perusahaan maupun sumber informasi 
Ulandari, et al/Jurnal Ekonomi Syariah Teori dan Terapan Vol. 7 No. 11 November 2020: 22672285

lainnya dan masih beroperasi hingga sekarang.

Sampel yang digunakan sebanyak 10 perusahaan berdasarkan kriteria yang ditentukan pada penelitian ini baik perusahaan yang bentuknya full fledge dan unit usaha syariah. sampel yang digunakan pada penelitian ini yaitu Asuransi Jiwa Al Amin, Amanahjiwa Giri Artha, Allianz Life Indonesia, AXA Financial, AXA Mandiri, Jiwa Central Asia Raya, Jiwa Manulife, Panin Daichi Life, Prudential Life Assurance, dan Tokio Marine Life Insurance.

\section{Teknik Analisis}

Penelitian ini menggunakan teknik analisis regresi data panel yaitu regresi gabungan antara data cross section dan time series. Data panel bisa dapat memberikan analisis yang mungkin tidak bisa digunakan jika kita menggunakan cross section atau time series saja (Gujarati \& Zhu, 2004).

\section{Uji Chow}

Uji Chow berfungsi untuk memilih kesesuaian model estimasi regresi data panel yang lebih baik antara Common Effect Model atau Fixed Effect Model, yang menggunakan uji F-statistik dengan hipotesis sebagai berikut (Widarjono, 2009:361):

HO: Common Effect Model

H1: Fixed Effect Model

Tingkat kepercayaan yang digunakan adalah sebesar 95\% (a 5\%). Apabila nilai F-statistik kurang dari 0,05 atau $<5 \%$ maka $\mathrm{HO}$ ditolak, sehingga $\mathrm{Hl}$ diterima dan fixed effect model atau FEM dipilih sebagai model regresi. Sedangkan jika lebih dari 0,05 atau $>5 \%$ maka $\mathrm{HO}$ diterima, sehingga common effect model atau CEM dipilih sebagai model regresi yang sesuai.

\section{Uji Hausman}

Uji Hausman dilakukan untuk memilih antara metode random effect atau fixed effect. Baltagi (2015:18) mengemukakan bahwa dalam menentukan model estimasi regresi data panel cukup menggunakan satu metode yakni uji hausman. Adapun hipotesis uji hausman adalah:

HO: Random effect model

$\mathrm{Hl}$ : Fixed effect model

Apabila nilai p-value pada uji hausman kurang dari 0,05 atau < 5\% maka HO ditolak. Sedangkan jika lebih dari 0,05 atau $>5 \%$ maka $\mathrm{HO}$ diterima

\section{Uji Lagrange Multiplier}

Uji untuk mengetahui apakah model yang tepat untuk digunakan Random Effect atau Common Effect. Uji signifikasi Random Effect ini dikembangkan oleh Breusch Pagan. Metode Bruesch Pagan untuk menguji signifikasi Random Effect didasarkan pada nilai residual dari metode Common Effect.

HO: Common Effect Model

$\mathrm{H} 1$ : Random Effect Model

Hlpotesisnya adalah jika Probabilitas Breush-Pagan (BP) lebih kecil dari Alpha $(0.0000<0.05)$ maka $\mathrm{H}_{0}$ ditolak dan $H_{1}$ diterima, jadi model yang tepat pada hasil diatas adalah random effect. Prob BP $(0,0103)<0,05$ maka HO ditolak, dengan kata lain model yang cocok adalah Random Effect Model. Hipotesis sebagai berikut: 
Ulandari, et al/Jurnal Ekonomi Syariah Teori dan Terapan Vol. 7 No. 11 November 2020: 22672285

\section{Model Regresi}

$Y_{i \dagger}=B_{i}+B_{1} R I S S I_{\text {it }}+B_{2}$ RISK $_{\text {if }}+\beta_{3}$ RPDB it $+\beta_{4}$

$\mathrm{BHD}_{\text {it }}+\mathrm{B}_{5} \mathrm{UKP}$ it $+\mathrm{B}_{6} \mathrm{PPSU}$ it $\mathrm{e}$

Ket: I = crosssetion

$t=$ timeseries

$B_{i}=$ koefesien konstanta

e = variabel error

RISSI = Return Saham ISSI

RISK = Risiko Saham ISSI

RPDB $=$ Pertumbuhan Ekonomi

BHD = Bagi Hasil Deposito

UKP $=$ Ukuran Perusahaan

PPSU=Pendapatan pembagian surplus underwritting

\section{Uji Hipotesis}

Uji T

Uji statistik $T$ bertujuan untuk menunjukkan seberapa jauh pengaruh suatu variabel independen secara individual atau masing-masing terhadap variabel dependen (Ghozali, 2011 : 98).

$\mathrm{HO}=$ Tidak terdapat pengaruh signifikan antara variabel independen terhadap variabel dependen secara parsial.

$\mathrm{H} 1$ = Terdapat pengaruh signifikan antara variabel independen terhadap variabel dependen secara parsial.

HO ditolak jika probability (t-stat) < a atau tingkat signifikansi 0,01 0.05, 0,10 (Mankiw, 2014: 379) yang menunjukkan bahwa secara parsial variabel independen berpengaruh signifikan terhadap variabel dependen dan sebaliknya.

Uji F

Uji Fisher (Uji-F) digunakan untuk mengetahui apakah seluruh variabel bebas (independen) secara bersamasama berpengaruh terhadap variabel terikat (dependen) pada tingkat signifikan 0,05 (Nachrowi, 2006: 16). Uji-F dilakukan dengan asumsi:

$\mathrm{HO}=$ Tidak terdapat pengaruh signifikan antara variabel independen terhadap variabel dependen secara simultan.

$\mathrm{H} 1$ = Terdapat pengaruh signifikan antara variabel independen terhadap variabel dependen secara simultan.

Bila probabilitas > a $5 \%$, maka variabel bebas tidak signifikan atau tidak mempunyai pengaruh terhadap variabel terikat begitu pula sebaliknya

\section{HASIL DAN PEMBAHASAN}

\section{Pemilihan Model Estimasi}

Tabel 2.

Hasil Uji Hausman

\begin{tabular}{|l|l|l|l|}
\hline Effects Test & Chi-Sq. Statistic & Prob. & Keterangan \\
\hline $\begin{array}{l}\text { Cross-section } \\
\text { random }\end{array}$ & 0.000000 & 1.0000 & H0 ditolak \\
\hline
\end{tabular}

Tabel 2 menunjukkan hasil uji hausman dengan probabilitas sebesar 1.0000. Namun, karena hasil estimasi random effect menunjukkan cross section 0 , artinya tidak ada pengaruh individual dalam data. Sehingga Fixed Effect Model (FEM) dipilih sebagai model estimasi yang sesuai.

Tabel 3.
Hasil Uji Chow
\begin{tabular}{|l|l|l|}
\hline Effect Test & Prob & Keterangan \\
\hline Cross-Section F & 0.9933 & H0 diterima \\
\hline
\end{tabular}

Tabel 3 menunjukkan hasil uji chow dengan probabilitas sebesar 0,00 yang artinya bahwa HO dlterima, sehingga Common Effect Model (CEM) dipilih sebagai model estimasi yang sesuai.

Tabel 4.

Hasil Uji LM

\begin{tabular}{|l|l|l|}
\hline $\begin{array}{l}\text { Null } \\
\text { Alternative }\end{array}$ & $\begin{array}{l}\text { Cross-section } \\
\text { One-sided }\end{array}$ & Both \\
\hline
\end{tabular}


Ulandari, et al/Jurnal Ekonomi Syariah Teori dan Terapan Vol. 7 No. 11 November 2020: 22672285

\begin{tabular}{|l|l|l|}
\hline $\begin{array}{l}\text { Breusch- } \\
\text { Pagan }\end{array}$ & 5.522394 & 317.4994 \\
$(0.0188)$ & $(0.0000)$ \\
\hline
\end{tabular}

Sumber: EViews9, data diolah

Tabel 4 menunjukkan hasil output di atas bahwa nilai Prob. Breusch-Pagan (BP) sebesar 0,0000 lebih kecil dari Alpha 0,05 sehingga menolak HO. Jadi berdasarkan uji LM, model yang terbaik digunakan adalah model dengan menggunakan Random Effect Model (REM).

Hasil estimasi regresi data panel diatas menunjukkan hasil yang berbedabeda. Untuk memilih model mana yang terbaik, lihat lagi dari tujuan penelitian. Jika keberagaman tidak menjadi bagian dari tujuan analisis, maka menggunakan model common effect. Namun jika terdapat analisis keberagaman dapat memilih fixed effect atau random effect. Berdasarkan pendapat dari Nachrowi (2006:318), jika data panel yang dimiliki mempunyai jumlah waktu (t) lebih besar dibandingkan jumlah perusahaan ( $n)$, maka disarankan menggunakan metode Fixed Effect. Sedangkan jika data panel yang dimiliki mempunyai jumlah waktu $(t)$ lebih kecil dibandingkan jumlah individu (n), maka disarankan menggunakan metode Random Effect. Penelitian ini menggunakan jumlah waktu selama 7 tahun dan jumlah perusahaan sebanyak 10 perusahaan. Sehingga model yang dipilih adalah menggunakan Random Effect Model.

Tabel 5.

Hasil Regresi Data Pane

\begin{tabular}{|l|l|l|l|l|}
\hline \multirow{2}{*}{} & \multicolumn{4}{|l|}{ Variabel Dependen: PROINV } \\
\cline { 2 - 5 } & Koefisien & Std. Error & $\begin{array}{l}\text { z- } \\
\text { statisti } \\
\text { k }\end{array}$ & Prob. \\
\hline C & 0,030759 & 0,023110 & 1,3309 & 0,1880 \\
\hline RISSI & $-1,101339$ & 0,140332 & - & 0,0000 \\
\hline
\end{tabular}

\begin{tabular}{|l|l|l|l|l|}
\hline RISK & $-0,956727$ & 0,154592 & $\begin{array}{l}- \\
6,1887\end{array}$ & 0,0000 \\
\hline $\begin{array}{l}\text { RPD } \\
\text { B }\end{array}$ & 0,404545 & 0,295885 & 1,3672 & 0,1764 \\
\hline BHD & $-0,138260$ & 0,077727 & $\begin{array}{l}- \\
1,7787\end{array}$ & 0,0801 \\
\hline UKP & 0,000220 & 0,000620 & 0,3544 & 0,7242 \\
\hline PPSU & $\begin{array}{l}5,0000028 \\
5\end{array}$ & $\begin{array}{l}0,0000089 \\
4\end{array}$ & 0,3186 & 0,7510 \\
\hline$R^{2}$ & 0,645925 & & $\begin{array}{l}\text { Dw- } \\
\text { stat }\end{array}$ & 3,4033 \\
\hline Obs & 70 & $\begin{array}{l}\text { Prob(F } \\
\text {-stat) }\end{array}$ & 0,0000 \\
0
\end{tabular}

Sumber: EViews9, data diolah

Berdasarkan hasil regresi data panel, return saham, risiko, dan bagi hasil deposito berpengaruh signifikan terhadap proporsi investasi dana perusahaan asuransi jiwa syariah pada saham syariah di Indonesia. Sedangkan pertumbuhan ekonomi, ukuran perusahaan dan pendapatan pembagian surplus underwriting tidak berpengaruh signifikan terhadap proporsi investasi dana perusahaan asuransi jiwa syariah pada saham syariah di Indonesia.

Berdasarkan hasil uji F pada tabel 5, nilai F-stat menunjukkan nilai sebesar 0,0000 yang lebih kecil dari $a=0,05$ dengan tingkat kepercayaan 95\%. Sehingga HO ditolak yang artinya bahwa RISSI, RISK, RPDB, BHD, UKP, dan PPSU secara simultan berpengaruh terhadap proporsi investasi saham.

Nilai koefisien determinasi atau $r$ square adalah sebesar 0,646 atau $65 \%$ yang menunjukkan bahwa variabel independen yang terdiri dari RISSI, RISK, RPDB, BHD, UKP, dan PPSU menjelaskan pengaruhnya terhadap variabel dependen proporsi investasi dana perusahaan pada saham syariah di Indonesia selama periode 2012 hingga 
Ulandari, et al/Jurnal Ekonomi Syariah Teori dan Terapan Vol. 7 No. 11 November 2020: 22672285

2018 sebesar $65 \%$. Sedangkan $35 \%$ sisanya dijelaskan oleh variabel lain di luar model.

\section{Pembahasan}

Dalam penelitian ini variabel meliputi return saham, risiko saham, pertumbuhan ekonomi, bagi hasil deposito, ukuran perusahaan dan pendapatan pembagian surplus underwriting sebagai variabel independen dan proporsi investasi dana perusahaan (PROINV) sebagai variabel dependen. Secara umum dalam periode penelitian $2012-2018$.

\section{Pengaruh Return Saham Terhadap Proporsi Investasi}

Berdasarkan hasil uji penelitian, tabel 5 menunjukkan return saham syariah yang diukur dengan rata-rata return geometric, secara statistik berpengaruh negatif signifikan terhadap proporsi investasi dana perusahaan (PROINV) dengan t-statistik -7,848 dan signifikansi 0,0000 yang lebih kecil dari 0,01 sehingga HO ditolak. Hasil penelitian ini tidak sesuai dengan teori yang menyatakan bahwa jika tingkat return saham naik, maka proporsi investasi juga akan naik.

Hal ini disebabkan karena pada periode tersebut, terjadi beberapa kejadian yang menyebabkan proporsi investasi menurun. Pertama, Indonesia sempat beberapa kali mengalami penurunan nilai tukar rupiah terhadap dolar Amerika Serikat (AS). Hal tersebut dapat menurunkan laju pertumbuhan investasi. Kedua, Bank Indonesia tercatat beberapa kali menaikan tingkat suku bunga acuannya (Bl rate) hingga level
7,5\%. Ketiga, terjadi kondisi pasar keuangan global yang sangat tidak pasti. Ketidakpastian tersebut diantaranya adalah ketidakpastian penarikan stimulus yang tinggi oleh The Fed. Keempat, terjadinya kenaikan Fed Fund rate (FFR), The Fed menaikkan suku bunga acuan sebanyak empat kali secara bertahap. Sehingga ada kemungkinan pelaku pasar akan menarik investasinya dari pasar modal dan mengalihkan ke dalam instrument yang lebih aman. Dan terakhir, kondisi politik ekonomi dunia juga sedang menghadapi gejolak yang kurang baik. Perang dagang antara Amerika Serikat (AS) dan Cina mulai memanas. Amerika Serikat kembali menerapkan kebijakan yang menyudutkan Cina. Amerika Serikat bersiap mengenakan tarif bea masuk impor produk lain dari Cina, setelah sebelumnya memberlakukan penetapan tarif impor baja dan aluminium.

\section{Pengaruh Risiko Terhadap Proporsi Investasi}

Hasil temuan penelitian menunjukkan bahwa risiko yang diukur dengan standar deviasi, secara statistik berpengaruh negatif signifikan terhadap proporsi investasi dana perusahaan dengan t-statistik sebesar -6,189 dan signifikansi 0,0000 yang lebih kecil dari 0,01 sehingga $\mathrm{HO}$ ditolak. Hasil pada penelitian ini sejalan dengan teori mengenai risiko investasi yang menyatakan bahwa semakin tinggi tingkat risiko yang dihadapi, maka semakin kecil proporsi investasinya. 
Ulandari, et al/Jurnal Ekonomi Syariah Teori dan Terapan Vol. 7 No. 11 November 2020: 22672285

Penelitian ini sejalan dengan penelitian Zhu \& Zhou (2009) yang menunjukkan pentingnya mengetahui return saham secara dinamis dan strategi optimalisasinya melalui analisis teknikal pada masalah kerugian alokasi asset. Alokasi aset merupakan fungsi dari risk aversion investor dan derajat kemungkinan return saham. Sehingga dapat dikatakan bahwa alokasi aset atau investasi dipengaruhi oleh risiko yang akan diperoleh investor. Pada penelitian Arouri et al., (2013) juga menunjukkan bahwa risiko berpengaruh signifikan terhadap proporsi investasi. Investasi pada produk keuangan Islam menghasilkan return yang tinggi. Return yang tinggi pada investasi produk Islam akan diikuti dengan risiko yang tinggi pula. Sehingga portofolio yang menggunakan produk keuangan Islam dapat mengurangi risiko sistematis yang akan meningkatkan expected return dan menghasilkan keuntungan diversifikasi yang signifikan. Hal ini sesuai dengan teori risiko, dimana jika tingkat risiko yang dihadapi investor tinggi, maka semakin kecil pula proporsi atau minat investor untuk menanamkan modalnya.

Risiko menjadi salah satu faktor dihindari oleh setiap orang maupun perusahaan, tak terkecuali perusahaan asuransi. Dalam dunia investasi, risiko dan return merupakan dasar dari pencapaian kesejahteraan para investor, mengingat adanya konsep "High risk high return". Konsep ini menjelaskan hubungan antara risiko dan return dalam investasi saham. Jika dalam kinerjanya saham syariah mampu menghasilkan return yang tinggi, maka risiko yang timbul juga tinggi. Risiko kerugian yang dialami oleh perusahaan asuransi dapat diminimalisir dengan cara melakukan diversifikasi portofolio.

Pengaruh Pertumbuhan Ekonomi Terhadap Proporsi Investasi

Hasil temuan penelitian menunjukkan pertumbuhan ekonomi yang diukur dengan PDB, secara statistik tidak berpengaruh terhadap proporsi investasi dana perusahaan dengan memiliki tstatistik sebesar 1,367 dan signifikansi 0,1764 yang lebih besar dari 0,05 sehingga $\mathrm{HO}$ diterima.

Hasil penelitian ini sesuai dengan teori dan penelitian terdahulu. Pada penelitian yang dilakukan (Ward et al., 2014), menyatakan bahwa pertumbuhan ekonomi tidak mempengaruhi perusahaan asuransi untuk berinvestasi. Pada dasarnya kondisi perekonomian setiap negara berbeda-beda. Hal tersebut dikarenakan oleh pengaruh sejumlah faktor, seperti budaya, peraturan, lingkungan hukum, peningkatan intermediasi keuangan dan dampak pertanggungan moral hazard. Selain itu dalam hasil penelitian (Sala-imartin \& Artadi, 2002) menjelaskan bahwa, tingkat investasi cenderung dipengaruhi oleh rendahnya kualitas institusi keuangan, ketidakstabilan politik dan sosial, intervensi dan regulasi yang berlebihan dari pemerintah, serta rendahnya kualitas sumber daya manusia menjadi faktor penentu pada tidak produktifnya keputusan investasi secara sistematis. 
Ulandari, et al/Jurnal Ekonomi Syariah Teori dan Terapan Vol. 7 No. 11 November 2020: 22672285

Kegiatan perekonomian yang meningkat pada suatu negara menunjukkan terjadinya peningkatan pada nilai PDB di negara tersebut. Artinya, negara tersebut sedang mengalami peningkatan aktivitas ekonomi, lebih banyak barang atau jasa yang dihasilkan. Akibatnya berpotensi pada peningkatan laba perusahaan, sehingga perusahaan dapat lebih besar menetapkan proporsi investasi. Sebaliknya, kegiatan perekonomian yang melemah menunjukkan penurunan nilai PDB di suatu negara. Artinya, negara tersebut mengalami penurunan aktivitas ekonomi berupa menurunnya output barang atau jasa yang dihasilkan. Hal demikian yang akan berpotensi menurunkan laba perusahaan. Meskipun kondisi pertumbuhan ekonomi baik, tetap akan ada perusahaan yang berpotensi mengalami penurunan aktivitas ekonomi. Pendatan usaha yang diperoleh perusahaan dari aktivitas ekonominya, tidak serta merta keseluruhan pendapatan tersebut akan di investasikan. Perusahaan asuransi juga memiliki beban usaha yang wajib dibayarkan.

\section{Pengaruh Bagi Hasil Deposito terhadap} Proporsi Investasi

Hasil temuan penelitian menunjukkan secara statistik bagi hasil deposito berpengaruh terhadap proporsi investasi dana perusahaan dengan tstatistik sebesar -1,779 dengan tingkat signifikansi 0,0801 yang lebih kecil dari 0,1. Artinya menolak $\mathrm{H}_{0}$ dan secara statistik bagi hasil deposito berpengaruh negative signifikan terhadap proprosi investasi dana perusahaan pada saham syariah.

Hasil penelitian ini memiliki makna yang sama dengan penelitian sebelumnya. Pada penelitian yang dilakukan Timami \& Soejoto (2013) menjelaskan bahwa, tingkat bagi hasil deposito secara signifikan mempengaruhi jumlah simpanan deposito mudharabah. Selain itu hasil penelitian dari Yesha (2018) menunjukkan bahwa tingkat bagi hasil berpengaruh positif signifikan terhadap simpanan deposito. Hal tersebut terjadi karena pengaruh hubungan searah antara tingkat bagi hasil dengan simpanan deposito. Artinya jika tingkat bagi hasil deposito yang diterima tinggi, maka akan meningkatkan simpanan deposito. Hasil penelitian tersebut sesuai dengan teori floating market, bahwa sebagian investor menyimpan vangnya pada bank. Penyebabnya lebih ketingkat keuntungan dan kualitas pelayanan yang ditawarkan. Apabila tingkat bagi hasil naik, maka nasabah akan menyimpan dananya dalam jumlah besar, agar mendapatkan keuntungan yang tinggi.

Hasil penelitian ini menunjukkan bahwa investor akan memasukkan dana lebih pada deposito, dibandingkan dengan saham. Karena investasi pada saham adalah salah satu jenis investasi yang tidak lepas dari istilah "high risk high return". Tingkat keuntungan yang diperoleh dari investasi pada saham bergantung pada pergerakan pasar. Sedangkan, keuntungan pada deposito tidak mengikuti pergerakan harga pasar. 
Ulandari, et al/Jurnal Ekonomi Syariah Teori dan Terapan Vol. 7 No. 11 November 2020: 22672285

Maka pendapatan deposito cenderung tetap atau stabil, sehingga risikonya pun rendah. Berbeda dengan keuntungan dari investasi pada saham. Karena keuntungan yang didapat dari saham bersifat fluktuatif tergantung pergerakan pasar. Sehingga jika tingkat bagi hasil deposito yang diterima lebih tinggi daripada saham, maka perusahaan asuransi jiwa syariah akan lebih mengoptimalkan dana yang dimiliki atau menambah proporsi investasi kedalam depostito, dibandingkan pada saham.

\section{Pengaruh Ukuran Perusahaan terhadap Proporsi Investasi}

$\begin{array}{ccr}\text { Hasil temuan } & \text { penelitian } \\ \text { menunjukkan } & \text { pengaruh } & \text { ukuran }\end{array}$
perusahaan terhadap proporsi investasi dana perusahaan pada saham syariah sebesar 0.7242 satuan. Artinya menerima $\mathrm{H}_{0}$. dan secara statistik tidak berpengaruh terhadap proprosi investasi dana perusahaan pada saham syariah.

Hasil penelitian ini memiliki hasil yang sejalan dengan penelitian terdahulu. Pada penelitian yang dilakukan oleh Yakob et al., (2015) menunjukkan bahwa, ukuran perusahaan tidak memberikan pengaruh yang signifikan terhadap efisiensi pengelolaan investasi perusahaan asuransi. Situasi ini kemungkinan karena peraturan yang ketat mengatur industri asuransi, khususnya dalam hal-hal yang berkaitan dengan kegiatan investasi. Hasil penelitian ini juga menunjukkan bahwa dana yang dimiliki perusahaan, tidak semuanya diinvestasikan. Sebagian dananya akan digunakan untuk keperluan lainnya seperti biaya operasional, biaya produksi dan biaya lainnya. Investasi pada saham tidak boleh melebihi jumlah dari tingkat presentase yang telah ditetapkan oleh OJK. Jadi, terlepas dari ukuran perusahaan, diversifikasi portofolio investasi dibatasi beberapa tingkat persentase dan pilihan portofolio.

Ukuran perusahaan yang tidak berpengaruh memiliki makna bahwa ukuran perusahaan bukan faktor pertimbangan perusahaan asuransi dalam menentukan besaran proporsi investasi. Meski perusahaan besar memiliki akses yang lebih besar untuk menginvestasikan dana yang dimiliki. Namun, disisi lain perusahaan dengan skala kecil lebih fleksibel dalam menghadapi ketidakpastian. Hal itu dikarenakan, perusahaan kecil lebih cepat bereaksi terhadap perubahan yang mendadak. Selain itu peneliti menduga bahwa, setiap perusahaan kecil maupun besar memiliki kesempatan berinvestasi yang sama. Ukuran perusahaan dinilai dari total aset yang dimiliki sebuah perusahaan. Namun, ukuran perusahaan bukan menjadi faktor utama bagi perusahaan asuransi dalam menentukan besaran proporsi investasi. Faktor yang lebih diutamakan yaitu tingkat return dan risiko. Kemara Dewi \& Badjra (2017) menyatakan ukuran perusahaan belum bisa menjamin bahwa dengan total aktiva yang besar dapat membuat perusahaan makmur.

Pengaruh Pendapatan Pembagian Surplus Underwriting terhadap Proporsi Investasi 
Ulandari, et al/Jurnal Ekonomi Syariah Teori dan Terapan Vol. 7 No. 11 November 2020: 22672285

Hasil temuan penelitian menunjukkan pengaruh pendapatan pembagian surplus underwriting terhadap proporsi investasi dana perusahaan sebesar 0,7510 satuan. Artinya menerima $\mathrm{H}_{0}$ dan secara statistik tidak berpengaruh terhadap proprosi investasi dana perusahaan pada saham syariah.

Surplus underwriting adalah selisih lebih total kontribusi peserta ke dalam dana tabarru' ditambah kenaikan aset reasuransi setelah dikurangi pembayaran santunan atau klaim, kontribusi reasuransi dan kenaikan cadangan teknis, dalam satu periode tertentu (OJK). Atau secara sederhananya jika dalam satu periode tidak ada klaim atau terjadi sedikit klaim dari nasabah, maka kelebihan dana yang disimpan pada bank tabarru' itulah yang disebut surplus underwriting. Hasil underwriting yang tinggi pada perusahaan asuransi, secara umum menunjukkan baiknya proses underwritting yang telah dilakukan oleh perusahaan. Sedangkan penurunan hasil underwriting menunjukkan melemahnya proses underwritting selama periode tertentu (Fikri, 2009).

Sesuai pada aturan Fatwa DSN No. 53/DSN-MUI/III/2006, jika terdapat surplus underwriting atas dana tabarru', maka boleh dilakukan beberapa pilihan tindakan. Pertama, seluruhnya digunakan untuk dana cadangan tabarru'. Kedua, disimpan sebagian sebagai dana cadangan dan dibagikan sebagian lainnya kepada para peserta asuransi sesuai syarat. Dan ketiga, disimpan sebagian sebagai dana cadangan, dibagikan sebagian kepada perusahaan asuransi dan perserta sesuai dengan kesepakatan. Besaran pendapatan pembagian atas surplus underwriting yang diterima perusahaan, nantinya akan dikelola perusahaan asuransi syariah sesuai kebijakan masing-masing perusahaan. Tidak serta merta, ketika pendapatan pembagian surplus underwitingnya tinggi, maka perusahaan akan menggunakan semuanya untuk investasi. Karena bisa jadi disisi lain, biaya operasional dan biaya lainnya ikut meningkat. Jika sebagian dari dana tersebut akan diinvestasikan kembali, maka besaran proporsi investasinya harus sesuai dengan peraturan Otoritas Jasa Keuangan Nomor 72/POJK.05/2016 tentang kesehatan keuangan perusahaan asuransi dan perusahaan reasuransi.

\section{v. SIMPULAN}

Penelitian ini dilakukan untuk menguji pengaruh return saham, risiko saham, pertumbuhan ekonomi, bagi hasil deposito, ukuran perusahaan, dan pendapatan pembagian surplus underwriting terhadap proporsi investasi dana perusahaan asuransi jiwa syariah pada saham syariah di Indonesia. Hasil dari penelitian ini menunjukkan bahwa return saham, risiko saham, dan bagi hasil deposito secara statistic berpengaruh terhadap proporsi investasi dana perusahaan asuransi jiwa syariah pada saham syariah. Sedangkan pertumbuhan ekonomi, ukuran perusahaan, dan pendapatan pembagian surplus underwriting secara statistic tidak 
Ulandari, et al/Jurnal Ekonomi Syariah Teori dan Terapan Vol. 7 No. 11 November 2020: 22672285

berpengaruh terhadap proporsi investasi dana perusahaan asuransi jiwa syariah pada saham syariah. Hasil dari penelitian ini dapat menjadi sebagai sebuah pertimbangan dalam membuat kebijakan menentukan besaran proporsi dana perusahaan yang akan diinvestasikan. Agar dapat memenuhi kewajiban untuk meningkatkan modal atau laba demi meningkatkan daya saing dan memperkuat kesehatan keuangan.

\section{DAFTAR PUSTAKA}

Alam Choudhury, M., \& Harahap, S. S. (2009). Complementing community, business and microenterprise by the Islamic epistemological methodology: A case study of Indonesia. International Journal of Islamic and Middle Eastern Finance and Management, 2(2), 139-159. https://doi.org/10.1108/1753839091 0965158

Arouri, M. E., ben Ameur, H., Jawadi, N., Jawadi, F., \& Louhichi, W. (2013). Are Islamic finance innovations enough for investors to escape from a financial downturn? Further evidence from portfolio simulations. Applied Economics, 45(24), 34123420.

https://doi.org/10.1080/00036846.20 12.707776

Badan Pusat Statistik. Laju pertumbuhan PDB seri 2010. Diakses dari https://bps.go.id

Bank Indonesia. Laporan perekonomian Indonesia tahun 2015. Diakses dari https://www.bi.go.id

Fatwa Dewan Syariah Nasional No. i21/DSN-MUI/X/2001 tentang Pedoman Umum Asuransi Syariah.

Fatwa Dewan Syariah Nasional No.i53/DSNMUI/III/2006 tentang Akad Tabarru' pada Asuransi Syariah.

Gujarati, D. N., \& Zhu, L. (2004). Basic econometrics. United States: MC Graw-Hill Companie.

Kane, S. N., Mishra, A., \& Dutta, A. K. (2016). Preface: International conference on recent trends in physics (ICRTP

2016). Journal of Physics: Conference Series, 755(1). https://doi.org/10.1088/17426596/755/1/011001

Kemara Dewi, A., \& Badjra, I. (2017). Pengaruh profitabilitas, aktiva tidak berwujud, ukuran perusahaan, dan struktur modal terhadap nilai perusahaan. E-Jurnal Manajemen Universitas Udayana, 6(4).

Kinoshita, Y. (2005). Firm size and determinants of foreign direct investment. SSRN Electronic Journal. https://doi.org/10.2139/ssrn.154611

Nachrowi, D. N., \& Hardius, U. (2002). Penggunaan teknik ekonometrika. Jakarta: Raja Grafindo Persada.

Nachrowi, D. N., \& Hardius, U. (2006). Pendekatan populer dan praktis ekonometrika untuk analisis ekonomi dan kevangan. Jakarta: LPFE Universitas Indonesia.

Nazir, M. (2003). Metode penelitian. Jakarta: Ghalia Indonesia.

OJK (2013). Statistik Perasuransian Indonesia Tahun 2012.

(2014). Statistik Perasuransian Indonesia Tahun 2013.

(2015). Statistik Perasuransian Indonesia Tahun 2014.

(2016). Statistik Perasuransian Indonesia Tahun 2015.

(2017). Statistik Perasuransian Indonesia Tahun 2016.

(2018). Statistik Perasuransian Indonesia Tahun 2017.

(2019). Statistik Perasuransian Indonesia Tahun 2018.

(2018). Statistik Perbankan Syariah Tahun 2018.

(2016). Peraturan Otoritas Jasa Keuangan Nomor 72/POJK.05/2016.

Priyono, E. A. (2003). Bahan kuliah metodologi penelitian. Program Studi Magister Kenotariatan Universitas Diponegoro, Semarang.

Raza, S. A., Ahmed, R., Ali, M., \& Qureshi, M. A. (2019). Influential factors of Islamic insurance adoption: an extension of theory of planned behavior. Journal of Islamic Marketing, $11(6), \quad$ 1497-1515. https://doi.org/10.1108/JIMA-032019-0047

Sherif, M., \& Azlina Shaairi, N. (2013). 
Ulandari, et al/Jurnal Ekonomi Syariah Teori dan Terapan Vol. 7 No. 11 November 2020: 22672285

Determinants of demand on family Takaful in Malaysia. Journal of Islamic Accounting and Business Research, $\quad 4(1)$, 26-50. https://doi.org/10.1108/1759081131 1314276

Timami, M. F., \& Soejoto, A. (2013). Pengaruh dan manfaat bagi hasil terhadap jumlah simpanan deposito mudharabah bank syariah mandiri di Indonesia. Jurnal Pendidikan Ekonomi, 1 (3), 1-15.

Virlics, A. (2013). Investment decision making and risk. Procedia Economics and Finance, 6(13), 169177. https://doi.org/10.1016/s22125671(13)00129-9

Ward, D., Zurbruegg, R., \& Zurbruegg, R.
(2014). Does insurance promote economic growth? Evidence from OECD Countries. The Journal of Risk and Insurance, 67 (4), 489-506.

Yakob, R., Yusop, Z., Radam, A., \& Ismail, N. (2015). The relative efficiency of investment management of life insurers and takaful operators. Investment Management and Financial Innovations, 12 (1), 78-89.

Zhu, Y., \& Zhou, G. (2009). Technical analysis: An asset allocation perspective on the use of moving averages. Journal of Financial Economics, 92(3), 519-544. https://doi.org/10.1016/j.jfineco.200 8.07.002 